\title{
Testing time for gene patent as Europe rebels
}

Meredith Wadman, Washington

A European rebellion against the patent on a gene for breast cancer held by US company Myriad Genetics is gathering pace.

Paris's Curie Institute and the nearby Gustave Roussy Institute will next week file a formal objection to the patent, which covers the diagnostic test for the BRCA1 gene (see Nature 413, 95-96; 2001). But this move is just one aspect of the mounting opposition the patent faces across Europe.

Despite Myriad's request that all test samples be sent to its labs in Salt Lake City, scores of geneticists and dozens of diagnostic labs throughout Europe are still doing their own $B R C A 1$ testing. They say they are reluctant to concede their independence to a firm whose costs substantially exceed their own.

Bernhard Weber, head of breast cancer genetic testing at the Institute of Human Genetics in Würzburg - one of 12 nonprofit labs that between them carry out the bulk of genetic testing in Germany - says that, to his knowledge, not one of the labs has begun sending samples to Myriad. "There was a resentment in the group, in all 12 centres, saying 'We do not want to support this patent," says Weber. "We need to get our own results based on our own technology."

In the Netherlands, the network of eight labs that conducts all of the country's genetic testing is actively seeking legal avenues to block the Myriad patent. "We have developed a test in our own labs. It works. It is not more expensive than Myriad's. And now we should start paying royalties to Myriad?" says Bert Bakker, a molecular geneticist who heads the diagnostic lab in Leiden.

In Britain, National Health Service laboratories have continued their own BRCA1 testing, while the health department negotiates with Myriad over the extent to which they will have to submit samples. Although British geneticists say they will abide by any negotiated agreement, their anger at Myriad runs deep. "Myriad wants to enforce a monopoly on the provision of a service. That is an unwarranted and novel restriction on medical practice," says Rob Elles, secretary of the British Society for Human Genetics, who is in charge of molecular genetic testing in the regional lab at St Mary's Hospital in Manchester.

This resistance reflects broader sentiment against the patenting of human genes in Europe, researchers say. It may be a harbinger of tough times for companies who seek to exploit gene-based discoveries there.

"The substance patents now being given to the human genome are inappropriate and endanger research and medicine. Information about the human genome can't be invented. It is the common heritage of all humans," says Otmar Kloiber, senior executive of the German Medical Association.

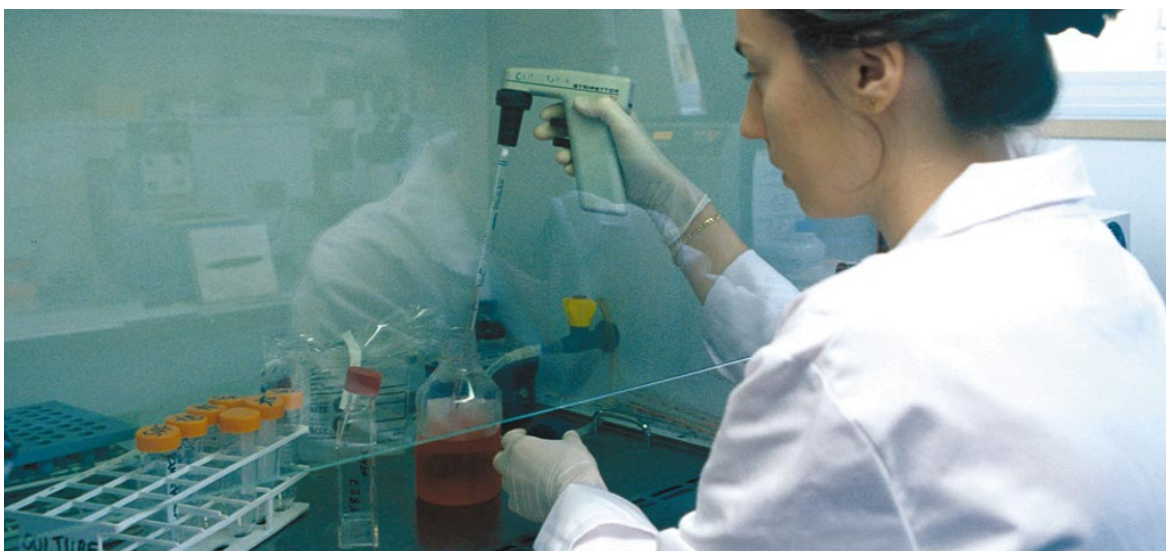

Hands off: Curie researchers are ignoring Myriad's patent by continuing to do their own BRCA1 tests.

Mike Stratton, head of the cancer genome project at the Sanger Centre near Cambridge, says: "The big question is whether naturally occurring DNA sequences are really up for grabs in the way that Myriad has indicated, and whether it is possible really to implement the patents that they get."

Myriad, which discovered BRCA1 in 1994 and has since poured tens of millions of dollars into developing its $\$ 2,680$ test, has cornered the market in the United States, where it has faced little public criticism.

Myriad claims it has every right to profit similarly in Europe. Although it has so far taken no steps to enforce its patent, it would be "very premature" to rule out such action, says Gregory Critchfield, who heads the genetic-testing division: "We have an obligation to protect our intellectual property."

Some experts say geneticists must come to terms with a new era in which diagnostic products are increasingly expensive - and proprietary. "The knee-jerk reaction of the research and medical communities is to say 'stop the patents'," says Rebecca Eisenberg, an expert in patent law at the University of Michigan. "That's not going to happen, so I'd like to see what their backup position is."

\section{Last-minute floods sink research}

\section{Alison Abbott, Munich}

Floods caused by a violent storm have badly damaged two research institutes run by the CNR, Italy's national research council, just a few weeks before half of their researchers were due to move into new premises.

The International Institute of Genetics

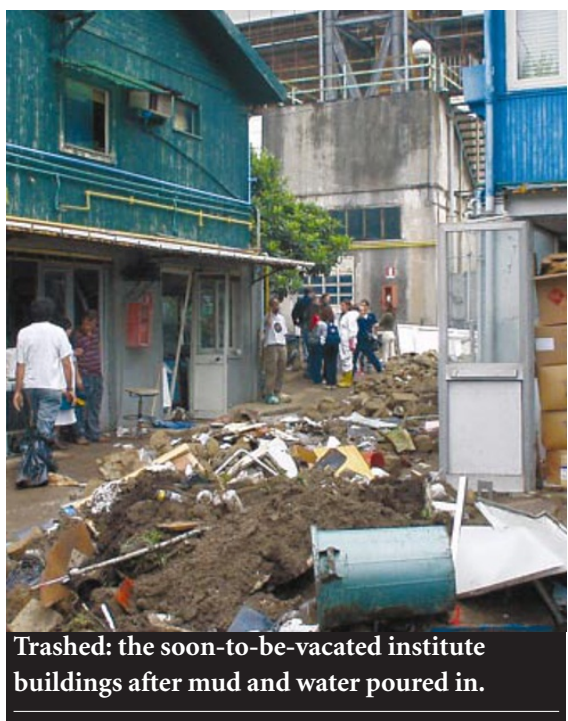

and Biophysics (IIGB) and the Institute of Protein Biochemistry and Enzymology, both based in Naples, were hit by floods on 15 September. They were preparing to relocate to the new Integrated Centre for Biological Research in the same city.

The floods ruined electron and confocal microscopes, causing an estimated 2.5 million euros (US\$2.3 million) damage. But scientists are most upset by the loss of data and of collections of knockout and transgenic organisms including the fruitfly Drosophila and the worm Caenorhabditis elegans.

Most of the IIGB's knockout and transgenic mice were killed - only those in cages on high racks survived as water and mud poured into the animal house to a height of two metres. "Fortunately the flood hit at 5 a.m. when no one was about, and there were no casualties," says IIGB director John Guardiola.

IIGB scientists say that the 'temporary' premises — in use since 1962 - were highly susceptible to flooding. The CNR had been promising a relocation for 25 years, they say. Half the laboratories were due to move this month, with the rest following next year. 